\title{
An integrated model of the adoption and extent of e-commerce in firms
}

\author{
Jordi Vilaseca, Joan Torrent, Antoni Meseguer and Inma \\ Rodríguez-Ardura \\ Internet Interdisciplinary Institute, \\ Open University of Catalonia (Universitat Oberta de Catalunya, or UOC) \\ Avda. Tibidabo 39-43, 08035 Barcelona, Spain
}

\author{
Author Posting. (c) 'Copyright Holder', 2007. \\ This is the author's version of the work. It is posted here for personal use, not for redistribution. \\ The definitive version was published in International Advances in Economic Research, Volume 13 Issue 2, 2007.
}

\begin{abstract}
Introduction
Since the mid-1990s researchers have sought to understand why some firms embark on e-commerce operations on the Internet while others prefer to wait and see how events unfold. We still have to determine which variables contribute to explaining the extent to which firms use e-commerce, given that to date the literature has not yet offered conclusive evidence on this question. The current work aims to provide an integrated vision of the set of factors influencing the e-commerce adoption process. We use a sample of 2,038 firms of all types that trade their products either with other organizations or with end-consumers.

For this purpose, we first identify and evaluate the impact of the internal and external factors leading firms to opt to develop an Internet-based e-commerce capacity. Given that little empirical evidence exists about how companies are managing change in the context of e-commerce [Cope \& Waddell, 2001], we also aim to identify the types of factors that, once firms adopt e-commerce, help them to generate a certain volume of business, allowing this medium to achieve a particular importance compared to the other marketing channels that the organization may use. Finally, we aim to evaluate to what extent the types of factors influencing e-commerce adoption and those influencing the subsequent development of e-commerce operations coincide. This will allow us to determine if firms are taking into account in their adoption decisions those elements that will influence the subsequent performance of their e-commerce operations.
\end{abstract}

\section{Previous studies on adoption of Internet as a marketing channel}

We have been able to identify up to 26 works, described in 30 different articles, which have aimed to study either the factors leading firms to adopt the Internet and e-commerce or those elements influencing its development once the firm has adopted these technologies (see Appendix 1).

Much research has focused on specific sectors of the economy, such as commercial distribution [O'Keefe et al., 1998; Doherty et al., 1999], industry [Chan \& Swatman, 2000; Chaston \& Mangles, 2002; Kula \& Tatoglu, 2003], the communications sector [Vadapalli \& Ramamurthy, 1997], the banking and finance sector [Corbitt, 2000], or tourism [Raymond, 2001; Wang \& Cheung, 2004]. Researchers have often examined the specific problems faced by SMEs when they adopt and use ecommerce on the Internet [Auger \& Gallaugher, 1997; Poon \& Swatman, 1997, 1999; O'Keefe et al., 1998; Chappell \& Feindt, 2000; Jeffcoate et al., 2002; Feindt et al., 2002; Walczuch et al., 2000; Chaston \& Mangles, 2002; Daniel et al., 2002; McGowan \& Durkin, 2002; Sadowski et al., 2002; Kula \& Tatoglu, 2003; Matlay \& Addis, 2003; Fillis et al., 2004]. And while some studies analyze the determinants of B2B e-commerce operations [Chan \& Swatman, 2000; Bertschek \& Fryges, 2002; Eid et al., 2002; Eid \& Trueman, 2004], others have preferred to focus on B2C e-commerce [O'Keefe et al., 1998; Doherty et al., 1999; Corbitt, 2000; Raymond, 2001].

The different studies have contemplated numerous and varied factors or determinants: characteristics of the innovation; organizational characteristics; those linked to the firm's competitive environment; 
managers' characteristics; managers' involvement in the implementation of the innovation, etc. Studies even differ in their definition of the object of study. Thus, a first group of studies aims to explain the decision to adopt e-commerce [Auger \& Gallaugher, 1997; O'Keefe et al., 1998, etc.]. Another group of studies attempts to explain the adoption process as a whole, from taking the decision to adopt the innovation to the implementation and full development of commercial operations on the Internet. In turn, in this second group we can distinguish between some studies focusing on the process of adopting Internet-based e-commerce [for example, Bertschek \& Fryges, 2002], from other (more common) works that focus on the general process of Internet adoption. This latter group of studies contemplates e-commerce as just one of the possible uses of the Internet in the firm [for example, Raymond, 2001; Arnott \& Bridgewater, 2002, among others]. A third group of studies, meanwhile, analyzes the final result of the adoption process, for which they identify and explain the factors contributing to e-commerce success [Chappell \& Feindt, 2000; Eid et al., 2002; Eid \& Trueman, 2004; Feindt et al., 2002; Jeffcoate et al., 2002; Sung \& Gibson, 2005]. Finally, we might mention a few studies that analyze the relation between a specific variable and e-commerce implementation [Chaston \& Mangles, 2002; Matlay \& Addis, 2003].

With regards to the methodologies employed, we note that some of the works (relatively few) are exclusively theoretical in nature [Eid et al., 2002; Fillis et al., 2004; Kim \& Galliers, 2004], while others have opted to use case studies and qualitative methodologies of analysis [Poon \& Swatman, 1997, 1999; Chan \& Swatman, 2000; Chappell \& Feindt, 2000; Corbitt, 2000; Feindt et al., 2002; Jeffcoate et al., 2002; Matlay \& Addis, 2003]. Empirical works are consequently the most frequent. But with the exception of Bertschek \& Fryges [2002], Daniel et al. [2002] \& Doherty et al. [1999], who use samples of 3000, 678 and 330 firms, respectively, all the other authors employ samples of under 300 firms. Moreover, some studies obtain their data exclusively from those firms that have adopted Internet or e-commerce, ignoring those companies preferring not to adopt this marketing channel [Auger \& Gallaugher, 1997; O'Keefe et al., 1998; Bertschek \& Fryges, 2002; Daniel et al., 2002, among others].

In view of all this, research need to continue advancing in the study of e-commerce adoption, and make contributions that offer broad conclusions about the role played by the characteristics of the firm and its competitive environment, both in the decision to adopt (or not) e-commerce, and in the extent to which e-commerce subsequently develops in the firm. Likewise, it would clearly be useful to cut the varied number of determinants identified up to now to a smaller number of critical factors.

\section{Conceptual framework}

Works that have studied the diffusion and adoption of relatively complex technologies like IT have frequently been framed in the analysis of processes of innovation diffusion and adoption [for example, Grover \& Goslar, 1993; Premkumar et al., 1994; King \& Teo, 1996; Ramamurthy et al., 1999; Thong, 1999]. This theoretical basis has allowed researchers to examine the relation between the characteristics of the IT, of its potential adopters, and of the environment, on the one hand, and the speed and extent that firms adopt or implement these innovations, on the other [Premkumar et al., 1994]. Hence it is hardly surprising that many studies on the adoption of Internet and e-commerce systems have also resorted to innovation diffusion theory [for example, Kim \& Galliers, 2004; Corbitt, 2000; Raymond, 2001]. However, it is equally true that researchers have paid relatively less attention to the diffusion of Internet and e-commerce [Kim \& Galliers, 2004] than they have to the diffusion of other information and communication technologies. Conceivably, this is largely due to the fact that firms started to use the Internet more recently.

At this point, we might ask if the adoption of e-commerce on the Internet needs to be examined in isolation, as various authors propose [Poon \& Swatman, 1997, 1999; Chan \& Swatman, 2000; Kim \& Galliers, 2004]. In this respect, we should note that some researchers [such as Downs \& Mohr, 1976; Fichman \& Kemerer, 1993; Kimberly \& Evanisko, 1981] have questioned the possibility of developing a single theory on adoption and diffusion that can be applied to all types of innovation. According to this stream of opinion, we cannot expect a single theory to adequately explain the adoption of different innovations, with their extremely different contexts of adoption [Thong, 1999]. It is precisely this interest in establishing a general theory of innovation diffusion that has, in the 
opinion of authors such as Fichman \& Kemerer [1997], led many researchers to take a theoretical approach, ignoring specific innovations and their particular adoption contexts. As a consequence of this, scholars seem to have put less emphasis on obtaining solid and consistent empirical findings about the specific determinants affecting each type of innovation. Furthermore, this trend seems to have been particularly strong in the area of IT adoption [Fichman, 1992]. In view of this lack of a single general theory on innovation adoption, some authors [for example, Fichman \& Kemerer; 1997; Thong, 1999; Raymond, 2001] propose an alternative approach that involves designing specific theories [Fichman, 2000] that take into consideration the distinctive characteristics and contexts of each type of technology.

Even if we accept the need to study IT adoption in isolation, the question still arises of whether we should study the assimilation of Internet and e-commerce specifically and separately from the other technologies of this type. But it seems clear that although the Internet is an information and communication technology, it has characteristics that distinguish and differentiate it from other such technologies. Thus, and unlike the e-commerce technologies that preceded it, which were based on closed networks, the Internet allows different agents to intervene in the transactions (firms, endconsumers, public administrations), admits an unlimited number of participants, is open to the global market, and requires the introduction of additional systems to ensure the transmission of information.

Researchers do debate, however, whether the particular characteristics of the Internet as a commercial environment make this medium a radical innovation or not [Lee, 2001; MacGregor, 2004]. While authors such as Hoffman \& Novak [1996] consider that the "paradigm shift" in marketing caused by the appearance of the Internet is bigger than any previous communications medium has generated, others consider that the Internet has not made such a big difference to the way people do business. Authors such as Chaffey et al. [2003] and Strauss et al. [2003] take an intermediate position, which holds that most of the principles guiding business practice remain valid on the Internet, but that some strategies and tactics do need to be adapted before they can be applied in this medium. In any case, it seems increasingly accepted that Internet-based e-commerce has certain differentiating attributes, such as the following:

- Interactivity and connectivity. On the one hand, the Internet's high degree of interactivity allows firms to intensify their relationships with their customers, by means of more direct communications adapted to their individual characteristics and behaviors. And on the other, the Internet's open and global nature is the source of its connectivity, offering a shared global space for communications and commercial exchanges [Dutta et al., 1997]. The combination of both characteristics facilitates 1:1 segmentation [Blattberg \& Deighton, 1991], consumers' participation in new product development, the possibility of offering dynamic and personalized prices, communication with large audiences but tailored to each particular interlocutor, and the use of direct and continuous links in distribution [Benjamin \& Wingand, 1995].

- Network externalities. As the number of people and organizations using the Internet and ecommerce grows, so does the utility of the set of users [Vilaseca \& Torrent, 2004].

- Knowledge goods. Knowledge is increasingly being seen not only as a productive resource but also as a product that is exchangeable and hence a source of income. E-commerce seems to be becoming a commercial format that is particularly suited to trading knowledge goods, since this type of product is so easy to copy and distribute through the medium, and the variable costs of doing so are so low [Shapiro \& Varian, 1999].

- Convenience and low prices. Unlike what had been happening in conventional commercial distribution, e-commerce allows firms to exploit the competitive advantages of low prices simultaneously with high levels of convenience. On the one hand, the absence of physical establishments and the automation of certain functions of presentation and sales reduce operational costs. On the other, firms can offer customers broader and deeper product ranges, full information about the products and with absolutely no physical or temporal constraints hampering their purchase decisions [Rodriguez \& Ryan, 2000].

Consequently, we aim to define a specific model on the adoption and extent of e-commerce on the Internet, without forgetting that the Internet is an IT. Hence we have taken into account the specific literature on Internet and e-commerce diffusion, together with the literature on the diffusion of IT in 
general. And since current empirical findings on e-commerce adoption have thrown up some contradictions, while leaving some gaps at the same time, we have also needed to examine the literature on e-marketing to help us identify the determinants and discover their relations with the adoption and extent of e-commerce. As a result of our review of the literature in these three areas (Internet diffusion, IT diffusion and e-marketing), and considering the different works that have offered classifications of the determinant factors of e-commerce adoption [e.g., Grover \& Goslar, 1993; Avlonitis et al., 1994; Thong, 1999; Fillis et al., 2004], we have considered six different types of factors that conceivably influence the adoption and extent of e-commerce on the Internet: the characteristics of the competitive environment; the organizational characteristics of the firm; its strategic orientation; its innovative capacity; its managers' characteristics; and the IT equipment possessed and the uses the firm makes of it.

The competitive environment in which a firm operates conceivably influences the firm's propensity to adopt e-commerce. Indeed, the literature provides empirical evidence that firms operating in particular competitive environments use IT innovations more intensively [Yap, 1990; Thong, 1999], or even are more predisposed to adopt the Internet [Chappell \& Feindt, 2000]. However, the evidence is weaker when the object of analysis is the adoption of the Internet for commercial purposes [Sadowski et al., 2002]. Indeed, some authors have actually failed to demonstrate the existence of such a relation [Arnott \& Bridgewater, 2002]. One aspect of the competitive environment that researchers have considered particularly relevant in decisions to adopt e-commerce is the level of internationalization of the sector in which the firm operates [Bertschek \& Fryges, 2002]. Indeed, domestic firms competing against firms from other countries may feel more threatened by the presence of foreign competitors, encouraging them to explore new ways of maintaining or extending their competitive advantages by adopting innovations. However, we still lack arguments capable of explaining how the presence of foreign competitors in the sector affects the extent of e-commerce in the firm, or the results from such operations. In accordance with this, we formulate the following hypotheses:

H1a. Firms operating in more complex competitive environments are more highly predisposed to adopt e-commerce.

H1b. The firm's competitive environment is not significantly related to the extent of e-commerce.

Work on the diffusion of IT, and particularly that of e-commerce on the Internet, has studied the influence of various characteristics of the firm's organizational structure on the adoption of these innovations. Among these we might mention: the firm's level of internationalization [Arnott \& Bridgewater, 2002; Bertschek \& Fryges, 2002; Daniel et al., 2002; Kula \& Tatoglu, 2003]; its level of decentralization [Grover \& Goslar, 1993]; the methods the firm establishes for controlling work [Avlonitis et al., 1994]; the flexibility and adaptive capacity of the work teams [Durkin \& McGowan, 2001; Arnott \& Bridgewater, 2002]; the degree of collaboration or establishment of external alliances [Coviello \& Munro, 1995; Hsieh \& Kowang, 1996; Knight \& Cavusgil, 1996; Chen, 1999; Cagliano et al., 2003]; as well as the extent to which the firm outsources activities that are not critical to the running of its business [Webster, 1992; Achrol \& Kotler, 1999]. Taken together, it seems that companies with more complex and advanced organizational structures (those that are present in multiple markets, are more decentralized, non-hierarchical and flexible in structure, and build collaboration networks with other firms) adopt and implement e-commerce more easily. And it is logical to assume that those firms that have developed beyond simple and linear organizational models and adopted designs facilitating information flows will find it easier to take decisions aimed at adapting more closely to the evolving market (for example, adopting e-commerce), and subsequently leading, coordinating and supervising the implementation of the changes they have decided.

H2a. Firms with a higher degree of organizational complexity and orientation towards the network design are more highly predisposed to adopt e-commerce.

$\boldsymbol{H} \mathbf{2 b}$. Firms with a higher degree of organizational complexity and orientation towards the network design use e-commerce to a greater extent.

The firm's strategic orientation can play an important role in the adoption and extent of e-commerce [Raymond, 2001], and this in spite of the fact that we lack solid and pervasive conclusions about the influence of the market, marketing and relationship orientations [e.g., Chaston \& Mangles, 2002; LeeKelley et al., 2003] on the results of e-commerce operations. This is largely due to the positive role that these strategic orientations clearly play in general business performance [Narver \& Slater, 1990; 
Achrol \& Kotler, 1999; Avlonitis \& Gounaris, 1999; etc.]. Specifically, we can presume that those firms that strive most to follow the evolution of the market, identify the unmet needs of their consumers and use elements to strengthen customer relationships, will be more highly predisposed to adopt new commercialization channels like the Internet, since these channels are being used by an increasing proportion of consumers and customers. At the same time, we would suggest that this type of firm will use e-commerce more intensively, since this medium provides companies with excellent mechanisms and instruments to adapt their products to the needs of each segment and strengthen links with each customer.

H3a. Firms with a more complex strategic orientation (market, marketing or relationship oriented) are more highly predisposed to adopt e-commerce.

H3b. Firms with a more complex strategic orientation (market, marketing or relationship oriented) use e-commerce to a greater extent.

It is conceivable that more innovative firms will be more predisposed to discover or develop novel technological systems allowing them to design new products, processes or ways of organizing before their competitors [Shaw, 2000]. We still lack evidences demonstrating that once the decision to adopt e-commerce has been taken, this predictor will continue to have a role in explaining the performance of the e-commerce operations. But despite this, we might assume that given that electronic markets are dynamic and unstable, firms that are the best prepared to operate in them will introduce the changes required at each moment in time, and hence achieve the best results in this channel.

H4a. Innovative firms are more highly predisposed to adopt e-commerce.

H4b. Innovative firms use e-commerce to a greater extent.

Research has shown that the educational background of the firm's managers has a key role in IT adoption [Fichman \& Kemerer, 1997; Grover et al., 1997]. Similarly, and since the qualities of the firm's managers are determinant in their management practice [Rothwell, 1977], we might expect those firms with a more highly-qualified management team to extract the best returns from ecommerce [Chan \& Swatman, 2000; Bertschek \& Fryges, 2002]. However, we still lack evidence about which particular managerial characteristics are directly related to the firm's decision to adopt ecommerce, and this in spite of the fact that there is a demonstrated link between people's educational level and their individual predisposition to start using the Internet [GVU Center, 1999].

H5a. The educational level of the firm's managers is not significantly related to the predisposition to adopt e-commerce.

H5b. The educational level of the firm's managers is related to the extent to which the firm uses $e$ commerce.

An aspect that also conceivably influences the decision to adopt e-commerce is the organization's "openness" to IT in general [Bertschek \& Fryges, 2002], or digital literacy. Thus, firms employing technologies of this type (CRM, ERP, etc.), and management teams that are familiar with and use the Internet, may more easily be able to identify the implications that this medium will have for their organization, and understand the urgent need to adopt it. Hence they may be more ready to allocate resources to exploit the advantages of the medium [Poon \& Swatman, 1999; Chan \& Swatman, 2000; Matlay \& Addis, 2003; Wang \& Cheung, 2004]. However, this will not necessarily guarantee, on its own, the extent to which the firm engages in commercial operations in electronic markets, or the success of such initiatives.

H6a. Firms with more IT equipment and which use it more are more highly predisposed to adopt ecommerce.

H6b. The amount of IT equipment firms possess and use is not significantly related to the extent to which they use e-commerce.

FIGURE 1

Types of determinant factors of adoption and extent of e-commerce 


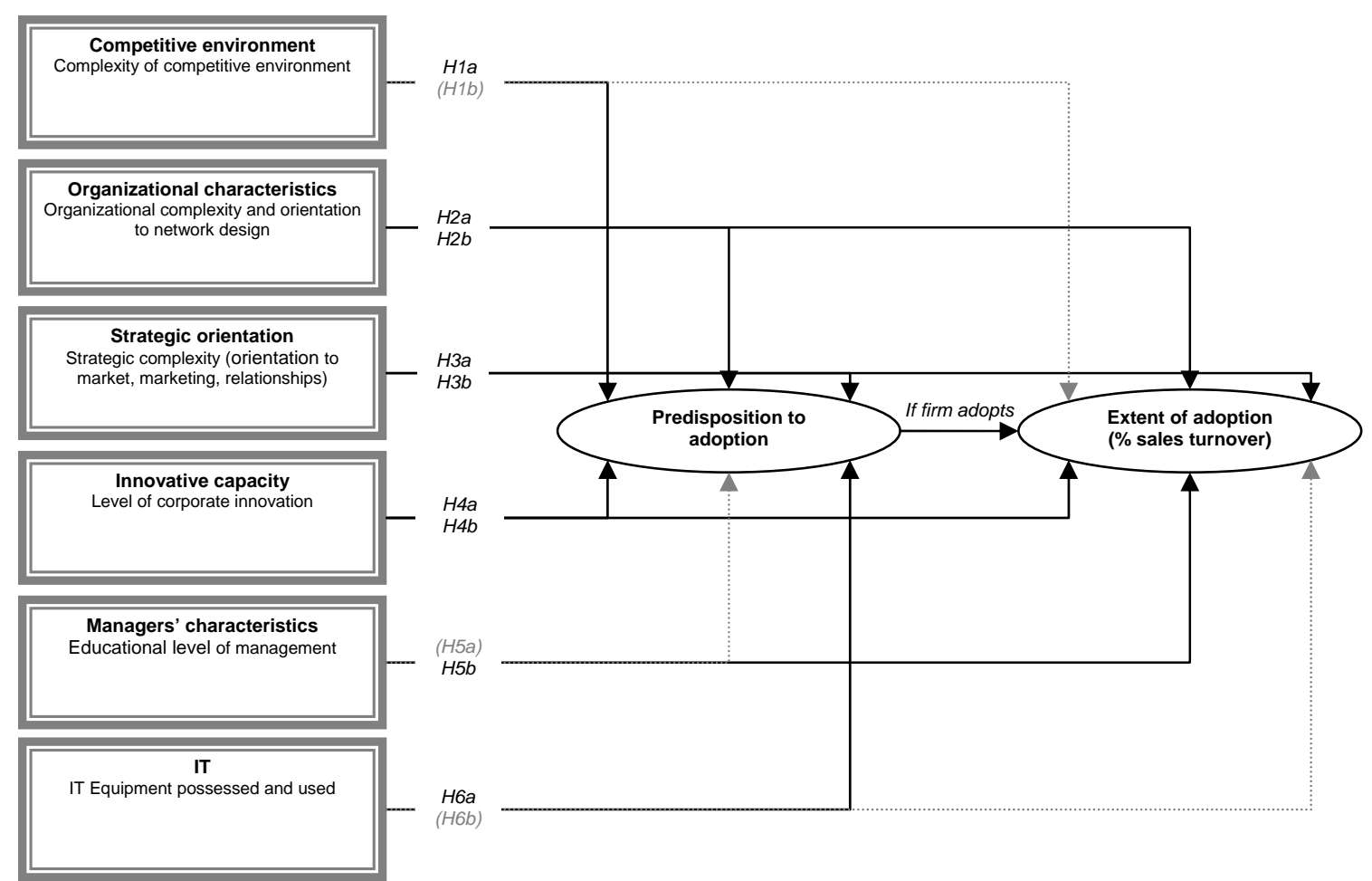

$\rightarrow$ : presumable impact on corresponding dependent variable; $\rightarrow$ : Presumably no relation with dependent variable.

\section{Methodology}

\section{Sample selection}

We obtained our data from a sample, stratified by firm size and sector of activity, of the firms engaged in economic activities in the region of Catalonia (Spain) in 2003. The sample units were selected at random from a database of 515,713 firms registered in the Central Directory of Firms of the Spanish National Statistics Institute (INE). The measuring instrument was a structured questionnaire completed in the course of a personal interview with the firms' owners or top managers. We designed the questionnaire after reviewing the academic literature, and taking into consideration the pilot test we carried out in November 2002. The definitive questionnaire was completed by 2,038 firms between January and May 2003. The interviews lasted one hour each and took place in the firms' premises. Our aim was for the respondents to provide information about their firms' business operations as a whole. The questionnaire comprised a total of 128 questions grouped in 13 different sections. For this particular work we considered 20 different variables (of the up to 500 variables included in the questionnaire).

\section{Variable measurement}

To measure Internet-based e-commerce adoption we used a dichotomous variable $(0 / 1)$, where 1 represents the adoption of the innovation and 0 its non-adoption. To measure the extent to which firms implement e-commerce, we took the proportion of the firm's total sales obtained through this channel. This measure has the added advantage that it also indicates the performance achieved by the ecommerce operations [Atuahene-Gima, 1996; Brentani, 1989]. To measure the different types of determinant considered (competitive environment, organizational characteristics, strategic orientation, innovative capacity, managers' characteristics, IT use) we created six numerical variables that express the level of complexity of each area of influence. These new indicators in fact capture the information provided by the original 18 variables corresponding to each type of influence.

\section{TABLE 1}

Definition of indicators used

\begin{tabular}{lccc}
\hline Factors & Variables & Description of values & Indicators \\
\hline Competitive environment & & &
\end{tabular}


Level of complexity of $\bullet$ Has competitors from rest of EU competitive

environment
- Has competitors from rest of world
Scale from 0 (No) to 1 (Yes)

Scale from 0 (No) to 1 (Yes)

Organizational characteristics

Level of organizational $\bullet \%$ sales in foreign markets

complexity and

orientation towards

network design $1(>33.3 \%)$
- Number of establishments

- Predominant form of control/supervision of work in firm

- Existence of flexible and adaptable work teams

- Firm carries out (or has carried out) operations with competitors

- \% of operations outsourced /subcontracted over total earnings

Strategic orientation
Level of strategic
complexity in
orientation to market,
marketing and
relationships

- Firm uses market research studies

- Firm segments its customers

- Firm maintains personalized relationship with each customer

\begin{tabular}{|c|c|c|c|}
\hline \multicolumn{4}{|l|}{ Innovative capacity } \\
\hline $\begin{array}{l}\text { Level of corporate } \\
\text { innovation }\end{array}$ & $\begin{array}{l}\text { - Firm has innovated in products in past } 2 \\
\text { years } \\
\text { - Firm has innovated in processes in past } 2 \\
\text { years } \\
\text { - Firm has innovated its organization in past } \\
2 \text { years }\end{array}$ & $\begin{array}{l}\text { Scale from } 0(\mathrm{No}) \text { to } 1 \\
\text { (Yes) } \\
\text { Scale from } 0(\mathrm{No}) \text { to } 1 \\
\text { (Yes) } \\
\text { Scale from } 0(\mathrm{No}) \text { to } 1 \\
\text { (Yes) }\end{array}$ & $\begin{array}{l}\text { Additive with respect } \\
\text { to variables } \\
\text { contemplated. Scale } \\
\text { from } 0 \text { to } 3\end{array}$ \\
\hline \multicolumn{4}{|c|}{ Managers' characteristics } \\
\hline $\begin{array}{l}\text { Managers' educational } \\
\text { level }\end{array}$ & $\begin{array}{l}\text { - Upper level of studies finished most } \\
\text { frequent among managers }\end{array}$ & $\begin{array}{l}\text { Scale from } 0 \text { (primary } \\
\text { studies) to } 2 \text { (university } \\
\text { studies) }\end{array}$ & $\begin{array}{l}\text { Additive with respect } \\
\text { to variable } \\
\text { contemplated. Scale } \\
\text { from } 0 \text { to } 2\end{array}$ \\
\hline \multicolumn{4}{|c|}{ IT Equipment possessed and used } \\
\hline $\begin{array}{l}\text { Level of IT equipment } \\
\text { held and used }\end{array}$ & $\begin{array}{l}\text { - Possession of integrated system for } \\
\text { obtaining and managing information with } \\
\text { customers (CRM) } \\
\text { - Possession of automated system for } \\
\text { planning with distributors (ERP) } \\
\text { - Have connected to Internet in past week }\end{array}$ & $\begin{array}{l}\text { Scale from } 0(\mathrm{No}) \text { to } 1 \\
\text { (Yes) } \\
\text { Scale from } 0(\mathrm{No}) \text { to } 1 \\
\text { (Yes) } \\
\text { Scale from } 0(\mathrm{No}) \text { to } 1 \\
\text { (Yes) }\end{array}$ & $\begin{array}{l}\text { Additive with respect } \\
\text { to variables } \\
\text { contemplated. Scale } \\
\text { from } 0 \text { to } 3\end{array}$ \\
\hline
\end{tabular}

Scale from $0(<33.3 \%)$ to

Scale from 0 (1 estab.) to

1(>1 estab.)

Scale from 0 (by

hierarchy) to 1 (by

objectives/results)

Scale from 0 (No) to 1

(Yes)

Scale from 0 (No) to 1

(Yes)

Scale from $0(0 \%)$ to 1

$(>0 \%)$

Scale from 0 (No) to 1 (Yes)

Scale from 0 (No) to 1

(Yes)

Scale from $0(\mathrm{No})$ to 1

Scale from 0 (No) to 1

Additive with respect to variables contemplated. Scale from 0 to 3 contemplated. Scale from 0 to 6

Additive with respect to variables contemplated. Scale from 0 to 2

Additive with respect to variables

\section{Results}

In order to deepen our understanding of the Internet-based e-commerce phenomenon and its determinants we analyzed the joint interaction of the set of factors contemplated both in the decision to adopt the innovation as well as in its subsequent implementation. The correlation matrix between the indicators of the explanatory factors shows that the correlations are low (see Appendix 2), which means that a priori there is no problem of information overload. In order to determine the types of factors that most characterize firms undertaking e-commerce operations, rather than those abstaining from e-commerce, we used a discriminant analysis as analytical framework. The model obtained has a Wilks' Lambda of $0.932\left(\chi^{2}=72.769, \mathrm{df}=6, \mathrm{p}=0.000\right)$, so that it can be considered significant as a whole. In turn, the discriminant function correctly classifies $61.8 \%$ of the adopters and $67.3 \%$ of the non-adopters (globally, it correctly classifies $66.5 \%$ of the sample firms). Hence we can say that the discriminant function offers an adequate level of prediction. The discriminant loadings, or structure 
correlations, which indicate the level of proximity of the independent variables to the discriminant function, allowed us to identify the variables that most contribute to distinguishing e-commerce adopters from non-adopters. The discriminant variables identified correspond to the majority of the areas of influence considered, with the exception of those concerning the managers' characteristics.

TABLE 2

Discriminant analysis of probability of adopting Internet-based e-commerce

\begin{tabular}{|c|c|c|c|c|}
\hline & $\begin{array}{c}\text { Wilks' } \\
\text { Lambda }\end{array}$ & F value & Significance & $\begin{array}{l}\text { Discriminant } \\
\text { loadings }\end{array}$ \\
\hline \multicolumn{5}{|l|}{ Competitive environment } \\
\hline $\begin{array}{l}\text { Level of complexity of competitive } \\
\text { environment }\end{array}$ & 0.996 & 3.766 & 0.043 & 0.041 \\
\hline \multicolumn{5}{|l|}{ Organizational characteristics } \\
\hline $\begin{array}{l}\text { Level of organizational complexity and } \\
\text { orientation towards network design }\end{array}$ & 0.982 & 19.101 & 0.000 & 0.352 \\
\hline \multicolumn{5}{|l|}{ Strategic orientation } \\
\hline $\begin{array}{l}\text { Level of strategic complexity in orientation to } \\
\text { market, marketing and relationships }\end{array}$ & 0.974 & 27.424 & 0.000 & 0.314 \\
\hline \multicolumn{5}{|l|}{ Innovative capacity } \\
\hline Level of corporate innovation & 0.962 & 40.806 & 0.000 & 0.429 \\
\hline \multicolumn{5}{|l|}{ Managers' characteristics } \\
\hline Managers' educational level & 0.999 & 1.460 & 0.227 & -0.104 \\
\hline \multicolumn{5}{|l|}{ IT Equipment possessed and used } \\
\hline Level of IT equipment held and used & 0.965 & 37.575 & 0.000 & 0.459 \\
\hline \multirow[t]{2}{*}{ Wilks' Lambda } & $\begin{array}{l}\text { Wilks' } \\
\text { Lambda }\end{array}$ & Chi-square & DF & Significance \\
\hline & 0.932 & 72.769 & 6 & 0.000 \\
\hline
\end{tabular}

At a confidence level of $95 \%$, we find that the firms operating in more complex competitive environments, in which more international companies compete $(\mathrm{p}=0.043)$, feel more pressure to change the rules of the game, so that they try to create competitive advantages by using the Internet as a new channel to commercialize their products.

We find that the firms with a greater degree of organizational complexity and an orientation towards the network organization are more predisposed to undertake e-commerce operations $(p=0.000)$. Firms with advanced organizational designs, which combine and integrate various specialized activities (from their own business units, or as a result of various strategic alliances with other companies), which manage activities on the basis of knowledge rather than hierarchy, and which employ work teams of varying membership, are more agile at taking decisions to adapt themselves to a changing global demand, a demand which is increasingly using the Internet as a medium of communication and exchange.

Likewise, we find that advanced strategic designs, which are oriented to the market, founded on segmentation strategies, and strive to establish stable relationships or links with customers, allow organizations to detect early the business opportunities arising in electronic markets $(p=0.000)$. Similarly, the firm's general innovative capacity, in terms of products, processes or the organizational design itself, favors the adoption of the Internet as a new distribution channel $(\mathrm{p}=0.000)$.

Finally, the educational level of the firm's management is not, of itself, relevant in the decision to adopt e-commerce $(\mathrm{p}>0.200)$, while the extent to which the organization as a whole incorporates and uses IT is relevant $(p=0.000)$. This indicates that firms that base their jobs on active and networked tasks and on the flow of communication and knowledge between their members, are more capable of adopting the Internet.

We also examined the development of e-commerce among the group of 252 firms from the sample that have adopted this commercialization channel for their products. For this, we used a multiple linear regression, which allowed us to evaluate the relative importance of each type of factor considered in the joint explanation of the phenomenon. The proposed model explains $35.3 \%$ of the 
variance in the proportion of the total sales volume earned by e-commerce $\left(\mathrm{R}^{2}=0.353\right.$, adjusted $\mathrm{R}^{2}=0.328$ ). Multicollinearity between the independent variables is low (the tolerance values are between 0.667 and 0.941 , and the variance inflation factors are between 1.063 and 1.500) for the OLS estimators. Moreover, the model is significant globally (in the analysis of variance we obtained the value $\mathrm{p}=0.000)$.

TABLE 3

Regression analysis on sales turnover from e-commerce (\%)

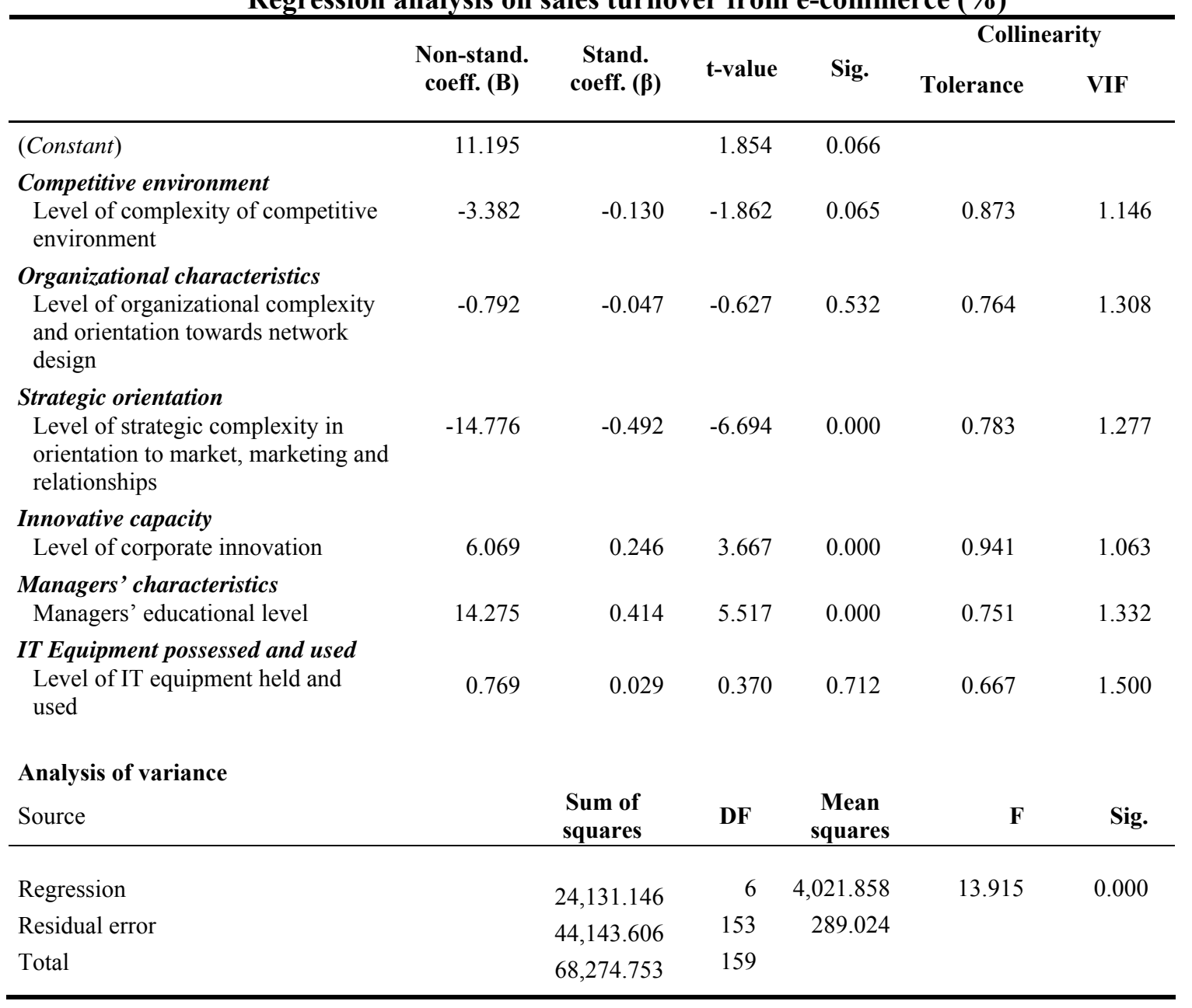

According to the results obtained for the coefficients of the indicators contemplated, the factors included in the solution, and which contribute significantly to the development of Internet-based ecommerce, are all firm-internal factors, i.e., aspects concerning companies' resources and capabilities. However, and in contrast to what we hypothesized, we have not been able to detect a significant relation between the set of organizational characteristics considered (advanced organizational designs, flexible work teams, collaboration with other firms, etc.) and the degree of implementation of ecommerce as a distribution channel ( $\mathrm{p}>0.500)$. A possible explanation for this is that it takes time for IT to have a positive impact on a firm's activities, a variable period of time for the firm to adequately integrate the IT into its structure [Brynjolfsson et al., 1994]. And given the short period of time since these firms have adopted e-commerce, we may not yet be able to detect the impact of the firms' organizational structure on the results of their e-commerce operations.

Furthermore, we find that strategic complexity contributes to the development of e-commerce, but, and contradicting our hypothesis, its contribution is negative $(\mathrm{B}=-14.776, \mathrm{t}=-6.694, \mathrm{p}=0.000)$, so it seems that firms with less complex strategic designs are best able to exploit e-commerce successfully. This result may highlight the need to examine additional strategic elements to those taken into account here, as well as to consider whether the conventional strategies of market and relationship orientations, as well as the segmentation strategies, require adaptation to the specific Internet 
environment if they are to have a positive impact on performance. Indeed, some previous work has also proved unable to clearly detect, for example, a positive relation between a relationship marketing orientation and improved performance on the Internet [Chaston \& Mangles, 2002; Lee-Kelley et al., 2003; Wang \& Cheung, 2004].

We demonstrate the existence of a significant relation between firms' general level of innovation and the extent to which they use e-commerce as a commercialization channel $(\mathrm{p}=0.000)$. This means that once firms have adopted the Internet they should continue to innovate in order to adapt better to electronic markets, which are dynamic and uncertain environments. Firms that are most prepared to make frequent changes to their products, methods or organizational values extract the most benefit from their presence in these markets.

Likewise, the management team's educational level is also relevant $(p=0.000)$ in the results achieved from e-commerce initiatives. Indeed, the firm requires highly-qualified managers if it is to lead and manage adequately the transformations brought about by embarking on business initiatives in electronic markets. This confirms, once again, that educational background is fundamental in a knowledge-based economy [Vilaseca \& Torrent, 2004].

Conversely, and as we hypothesized, once the decision to adopt e-commerce has been taken, and this innovation has been integrated adequately into the firm's operational applications and remaining information and communication technologies, the levels of IT equipment possessed and used are no longer relevant $(\mathrm{p}>0.500)$.

\section{Conclusions}

The range of factors influencing the decision to enter electronic markets to commercialize products is very wide and diverse, insofar as it includes aspects from the firm's competitive environment as well as firm-internal aspects (the company's organizational structure, strategy, degree of innovation, the extent to which it uses IT as a whole). However, the results achieved through e-commerce are particularly affected by a smaller number of factors, fundamentally internal ones: the firm's strategic orientation, its innovative capacity, and the managers' educational level.

Part of the decision to adopt e-commerce has an exogenous origin, insofar as the firms competing against more foreign companies feel they are under pressure to adopt e-commerce. However, this exogenous factor is not particularly relevant for driving e-commerce operations: the results that the firms end up achieving through this medium are fundamentally conditioned by the resources that they allocate to the initiative and the internal capacities available to them to exploit their presence on the Internet.

Similarly, organizational aspects appear to influence adoption decisions, while they are not particularly relevant in determining the success of e-commerce initiatives. On the one hand, the firms that have gone beyond the simplest organizational models, at times even organizing themselves in networks, are more agile at taking decisions, as they have created a structure that facilitates the flow of information and transfer of knowledge, in which their employees play a more active role in the decision-making. On the other hand, and in contrast to what we expected, the adoption of particular organizational forms is no guarantee of success on the Internet. This result may, however, change in future research, since the effective use of this new channel may require that firms introduce changes into their organization, changes which normally take some time to implement. More work is required in the future to further our understanding of this phenomenon.

The characteristics of the firm's strategy significantly influence the decision to adopt the Internet. In this way, firms that are oriented to market needs, to establishing lasting relationships with their customers and applying segmentation strategies in the markets in which they operate are more likely to adopt e-commerce. However, these strategies, in isolation, do not appear to be sufficient to explain the success of certain e-commerce initiatives. Thus, future research is required to analyze the impact of the strategy on e-commerce operations, and it should consider the possibility that the conventional strategies of market, marketing and relationship orientation may need to be adapted to the environment of this medium.

What is decisive, both for firms' decisions to introduce e-commerce as well as their subsequent implementation of this innovation, is the companies' innovative vocation. Firms that are most 
innovative in their products, processes and structures are the most keen to adopt the Internet, and given that they are the best prepared to introduce the changes that operating in a dynamic and unstable medium implies, these firms achieve the best results from their e-commerce initiatives.

The management team's educational level is particularly relevant in the implementation of ecommerce, a process in which managers need to lead, coordinate and supervise successfully a set of initiatives that are new to the firm. In contrast, the IT equipment previously possessed and used in the firm predisposes the company to adopt e-commerce.

The extent of the results obtained here is limited by the fact that the data comes from firms from a single country. This is because the barriers to adoption of new technologies [Parente \& Prescott, 1994] can differ from one territory to the next, due to the influence of cultural aspects [Phillips et al., 1994]. In any case, it is no less true that the work presented here provides a theoretical framework whose implications may prove interesting in view of the large sample we have used as a source for the data (2,038 firms).

We should also mention the fact that we have not taken into account when the firms adopted ecommerce, an aspect that would have allowed us to enrich our findings. We also obtained a relatively low percentage of variance $(35.3 \%)$ explained by the analytical model used here to study the factors influencing the extent of e-commerce implementation. Thus, subsequent work will be necessary to explore other mathematical functions and incorporate additional information, either in the same indicators or in new ones. Another important limitation is that we have not distinguished between $\mathrm{B} 2 \mathrm{~B}$ and $\mathrm{B} 2 \mathrm{C}$ e-commerce. This does, however, have the advantage of reflecting a holistic vision of e-commerce adoption. By means of the picture we have obtained here, we demonstrate that the factors influencing firms' e-commerce adoption decisions do not necessarily coincide with those factors that eventually help the organizations to generate higher sales volumes from their e-commerce operations.

\section{References}

Achrol R.S. \& Kotler P. (1999). Marketing in the network economy. Journal of Marketing, 63 (4), 146-163.

Arnott, D.C. \& Bridgewater, S. (2002). Internet, interaction and implications for marketing. Marketing Intelligence \& Planning, 20 (2), 86-95.

Atuahene-Gima, K. (1996). Market orientation and innovation. Journal of Business Research, 35 (2), 93-103.

Auger, P. \& Gallaugher, J.M. (1997). Factors affecting the adoption of an Internet-based sales presence for small business. The Information Society, 13 (1), 55-74.

Avlonitis, G.J. \& Gounaris, S.P. (1999). Marketing orientation and its determinants: an empirical analysis. European Journal of Marketing, 33 (11/12), 1003-1037.

Avlonitis, G.J. \& Kouremenos, A., Tzokas, N. (1994). Assessing the innovativeness of organizations and its antecedents: Project Innovstrat. European Journal of Marketing, 28 (11), 5-28.

Benjamin, R.I. \& Wingand, R.T. (1995). Electronic markets and virtual value chains on the information highway. Sloan Management Review, 36 (2), 62-72.

Bertschek, I. \& Fryges, H. (2002). The adoption of business-to-business e-commerce: empirical evidence for German companies. ZEV Discussion Paper, 02-05. Mannheim, Germany: Centre for European Economic Research. Available at ftp://ftp.zew.de/pub/zew-docs/dp/dp0205.pdf.

Blattberg, R.C. \& Deighton, J. (1991). Interactive marketing: exploiting the age of addressability. Sloan Management Review, 33 (1), 5-14.

Brentani, U.D. (1989). Success and failure in new industrial services. Journal of Product Innovation Management, 6 (4), 239-258.

Brynjolfsson, E., Malone, T., Gurbaxani, V. \& Kambil, A. (1994). Does information technology lead to smaller firms? Management Science, 40 (12), 1628-1644.

Cagliano, R., Caniato, F. \& Spina, G. (2003). E-business strategy. How companies are shaping their supply chain through the Internet. International Journal of Operations \& Production Management, 23 (10), 1142-1162.

Chaffey, D., Mayer, R., Johnston, K. \& Ellis-Chadwich, F. (2003). Internet marketing. Strategy, implementation and practice, Harlow, UK: Prentice Hall. 
Chan, C. \& Swatman, P.M.C. (2000). From EDI to Internet commerce: the BHP Steel experience. Internet Research: Electronic Networking Applications and Policy, 10 (1), 72-82.

Chappell, C. \& Feindt, S. (2000). Analysis of e-commerce practice in SMEs. Communications \& Strategies, 37 (1), 47-70.

Chaston, I. \& Mangles, T. (2002). E-commerce in small UK manufacturing firms: a pilot study on internal competencies. Journal of Marketing Management, 18 (3/4), 341-360.

Chen, W.H. (1999). Manufacturing strategies of networked-based small firms: observations on the textile industry in Taiwan. Journal of Small Business Management, 37 (2), 46-62.

Cope, O. \& Waddell, D. (2001). An audit of leadership styles in e-commerce. Managerial Auditing Journal, 16 (9), 523-529.

Corbitt, B.J. (2000). Developing intraorganizational electronic commerce strategy: an ethnographic study. Journal of Information Technology, 15 (2), 119-130.

Coviello, N.E. \& Munro, H.J. (1995). Growing the entrepreneurial firm: networking for international marketing development. European Journal of Marketing, 29 (7), 49-57.

Daniel, E., Wilson, H. \& Myers, A. (2002). Adoption of e-commerce by SMEs in the UK. International Small Business Journal, 20 (3), 253-70.

Doherty, N.F., Ellis-Chadwick, F. \& Hart, C.A. (1999). Cyber retailing in the UK: the potential of the Internet. International Journal of Retail \& Distribution Management, 27 (1), 22-36.

Downs, G.W. \& Mohr, L.B. (1976). Conceptual issues in the study of innovation. Administrative Science Quarterly, 21 (4), 700-714.

Durkin, M. \& McGowan, P. (2001). 'Net effect' - views from the periphery: exploring the ole and importance of the Internet on marketing activity in entrepreneurial firms. Irish Marketing Review, 14 (1), 15-25.

Dutta, S., Kwan, S. \& Segev, A. (1997). Transforming business in the marketspace: strategic marketing and customer relationships. CITM Working Paper, 97-WP-1023, Berkeley, CA: Fisher Center for Information Technology and Marketplace Transformation.

Eid, R. \& Trueman, M. (2004). Factors affecting the success of business-to-business international marketing (Bto-B IIM): an empirical study of UK companies. Industrial Management \& Data Systems, 104 (1), 13-30.

Eid, R., Trueman, M. \& Ahmed A.M. (2002). A cross-industry review of B2B critical success factors. Internet Research: Electronic Networking Applications and Policy, 12 (2), 110-123.

Feindt, S., Jeffcoate, J. \& Chappell, C. (2002). Identifying success factors for rapid growth in SME e-commerce. Small Business Economics, 19 (1), 51-62.

Fichman, R.G. (1992). Information technology diffusion: a review of empirical research. Proceedings of the Thirteenth International Conference on Information Systems. Dallas, Texas, 195-206.

Fichman, R.G. (2000). The diffusion and assimilation of information technology innovations. In R.W. Zmud, (Ed.). Framing the Domain of IT Management. Cincinnati, OH: Pinnaflex Educational Resources (pp. 105-127).

Fichman, R.G. \& Kemerer, C.F. (1993). Toward a theory of the adoption and diffusion of software process innovations. in L. Levine (Ed.). Proceedings of IKIP Conference on Diffusion, Transfer and Implementation of Information Technology (pp. 23-30).

Fichman, R.G. \& Kemerer, C.F. (1997). The assimilation of software process innovations: an organizational learning perspective. Management Science, 43 (10), 1345-1363.

Fillis, I., Johannson, U. \& Wagner, B. (2004). Factors impacting on e-business adoption and development in the smaller firm. International Journal of Entrepreneurial Behaviour \& Research, 10 (3), 178-191.

Grover, V. \& Goslar, M.D. (1993). The initiation, adoption, and implementation of telecommunications technologies in U.S. organizations. Journal of Management Information Systems, 10 (1), 141-163.

Grover, V., Fiedler, K. \& Teng, J. (1997). Empirical evidence on Swanson's tri-core model of information systems innovation. Information Systems Research, 8 (3), 273-287.

GVU Center. (1999). Tenth WWW User Survey. GVU's WWW User Surveys. Available at http://www.gvu.gatech.edu/gvu/user_surveys. 
Hoffman, D.L. \& Novak, T.P. (1996). Marketing in hypermedia computer-mediated environments: conceptual foundations. Journal of Marketing, 60 (3), 50-69.

Hsieh C.H. \& Kowang S.P. (1996). An observation of the growth of R\&D capabilities of small business in Taiwan: a case of CNC-controller manufacturer. Journal of Technology Management, 1 (1), 1-21.

Jeffcoate, J., Chappell, C. \& Feindt, S. (2002). Best practice in SMEs adoption of e-commerce. Benchmarking: An International Journal, 9 (2), 122-132.

Kim, C. \& Galliers, R.D. (2004). Toward a diffusion model for Internet systems. Internet Research: Electronic Networking Applications and Policy, 14 (2), 155-166.

Kimberly, J.R. \& Evanisko, M.J. (1981). Organizational innovation: the influence of individual, organizational and contextual factors on hospital adoption of technological and administrative innovations. Academy of Management Journal, 24 (4), 689-713.

King, W.R. \& Teo, T.S.H. (1996). Key dimensions of facilitators and inhibitors for the strategic use of information technology. Journal of Management Information Systems, 12 (4), 35-53.

Knight, G.A. \& Cavusgil, S.T. (1996). The born global firm: a challenge to traditional internationalisation theory. Advances in International Marketing, 8, 11-26.

Kula, V. \& Tatoglu, E. (2003). An exploratory study of Internet adoption by SMEs in an emerging market economy. European Business Review, 15 (5), 324-333.

Lee, C.S. (2001). An analytical framework for evaluating e-commerce business models and strategies. Internet Research: Electronic Networking Applications and Policy, 11 (4), 349-359.

Lee-Kelley, L., Gilbert, D. \& Mannicom, R. (2003). How e-CRM can enhance customer loyalty. Marketing Intelligence \& Planning, 21 (4), 239-248.

MacGregor, R.C. (2004). The role of strategic alliances in the ongoing use of electronic commerce technology in regional small business. Journal of Electronic Commerce in Organizations, 2 (1), 1-14.

Matlay, H. \& Addis, M. (2003). Adoption of ICT and e-commerce in small businesses: an HEI-based consultancy perspective. Journal of Small Business and Enterprise Development, 10 (3), 321-335.

McGowan, P. \& Durkin, M.G. (2002). Toward an understanding of Internet adoption at the marketing/entrepreneurship interface. Journal of Marketing Management, 18 (3/4), 361-377.

Narver, J.C. \& Slater, S.F. (1990). The effect of a market orientation on business profitability. Journal of Marketing, 54 (4), 20-35.

O'Keefe, R.M., O'Connor, G. \& Hsiang-Jui, K. (1998). Early adopters of the web as a retail medium: Small company winners and losers. European Journal of Marketing, 32 (7/8), 629-643.

Parente, S.L. \& Prescott, E.C. (1994). Barriers to technology adoption and development. Journal of Political Economy, 102 (2), 298-321.

Phillips, L.A., Calantone, R. \& Lee, M. (1994). International technology adoption: behaviour structure, demand certainty and culture. Journal of Business \& Industrial Marketing, 9 (2), 16-28.

Poon, S. \& Swatman, P. (1997). Small business use of the Internet. Findings from Australian case studies. International Marketing Review, 14 (5), 385-402.

Poon, S. \& Swatman, P. (1999). An exploratory study of small business Internet commerce issues. Information \& Management, 35 (1), 9-18.

Premkumar, G., Ramamurthy, K. \& Nilakanta, S. (1994). Implementation of electronic data interchange: an innovation diffusion perspective. Journal of Management Information Systems, 11 (2), 157-186.

Ramamurthy, K, Premkumar, G. \& Crum, M.R. (1999). Organizational and interorganizational determinants of EDI diffusion and organizational performance: a casual model. Journal of Organizational Computing and Electronic Commerce, 9 (4), 253-285.

Raymond, L. (2001). Determinants of web site implementation in small business. Internet Research: Electronic Networking Applications and Policy, 11 (5), 411-422.

Riquelme, H. (2002). Commercial internet adoption in China: comparing the experiences of small, medium and large businesses. Internet Research: Electronic Networking Applications and Policy, 12 (3), 276-286. 
Rodriguez, I. \& Ryan, G. (2000). The WWW in the food and beverage sector in Spain. International Advances in Economic Research, 6 (4), 699-709.

Rothwell, R. (1977). The characteristics of successful innovators and technically progressive firms. $R \& D$ Management, 7 (3), 191-206.

Sadowski, B.M., Maitland, C. \& Dongen, J.V. (2002). Strategic use of the Internet by small and medium-sized companies: an exploratory study. Information Economics and Policy, 14 (1), 75-93.

Shapiro, C. \& Varian, H.R. (1999). Information rules: a strategic guide to the network economy, Boston, MA: Harvard Business School Press.

Shaw, M.J. (2000). Electronic commerce: State of the art. In M.J. Shaw, R.W. Blanning, T.J., Strader, A.B. Whinston (Eds.). Handbook on electronic commerce, Berlin, Germany: Springer.

Strauss, J., El-Ansary, A.I. \& Frost, R. (2003). E-marketing on the Internet. Upper Saddle River, NJ: Prentice Hall.

Sung, T.K. \& Gibson, D.V. (2005). Critical success factors in electronic commerce: Korean experiences. Journal of Organizational Computing and Electronic Commerce, 15 (1), 19-34.

Tan, M. \& Teo, T.S.H. (1998). Factors influencing the adoption of the Internet. International Journal of Electronic Commerce, 2 (3), 5-18.

Thong, J.Y.L. (1999). An integrated model of information systems adoption in small business. Journal of Management Information Systems, 15 (4), 187-214.

Vadapalli, A. \& Ramamurthy, K. (1997). Business use of the internet: an analytical framework and exploratory case study. International Journal of Electronic Commerce, 2 (2), 71-94.

Vilaseca, J. \& Torrent, J. (2004). ICTs and transformations in Catalan companies. Barcelona, Spain: Universitat Oberta de Catalunya and Generalitat de Catalunya,.

Walczuch, R., Braven G.V. \& Lundgren, H. (2000). Internet adoption barriers for small firms in the Netherlands. European Management Journal, 18 (5), 561-571.

Wang, S. \& Cheung, W. (2004). E-business adoption by travel agencies: prime candidates for mobile ebusiness. International Journal of Electronic Commerce, 8 (3), 43-63.

Webster, F.E. (1992). The changing role of marketing in the corporation. Journal of Marketing, 56 (4), 1-17.

Yap, C.S. (1990). Distinguishing characteristics of organizations using computers. Information \& Management, $18(2), 97-107$.

APPENDIX 1

Summary of studies on firms' adoption of Internet and e-commerce

\begin{tabular}{|c|c|c|c|}
\hline $\begin{array}{l}\text { Author(s) and } \\
\text { year }\end{array}$ & $\begin{array}{l}\text { Object of } \\
\text { research }\end{array}$ & Scope of analysis & Determinants/critical factors \\
\hline $\begin{array}{l}\text { Auger \& } \\
\text { Gallaugher, } \\
1997\end{array}$ & $\begin{array}{l}\text { E-commerce } \\
\text { adoption }\end{array}$ & $\begin{array}{l}141 \text { small and medium-sized } \\
\text { manufacturers engaged in e-commerce } \\
\text { on Internet }\end{array}$ & $\begin{array}{l}\text { Low development and maintenance costs. Interest in } \\
\text { experimenting with channel. Wish to promote products and } \\
\text { build image. Financial considerations. Benefits of obtaining } \\
\text { and diffusing information }\end{array}$ \\
\hline $\begin{array}{l}\text { Poon \& } \\
\text { Swatman, } \\
1997 ; 1999\end{array}$ & $\begin{array}{l}\text { Internet adoption } \\
\text { process }\end{array}$ & $\begin{array}{l}23 \text { small firms with HQ in Australia } \\
\text { (case studies) }\end{array}$ & $\begin{array}{l}\text { Commitment of management. Perceived benefits of using } \\
\text { Internet }\end{array}$ \\
\hline $\begin{array}{l}\text { Vadapalli \& } \\
\text { Ramamurthy, } \\
1997\end{array}$ & Internet adoption & $\begin{array}{l}1 \text { large communications firm based in } \\
\text { US (case study) }\end{array}$ & $\begin{array}{l}\text { Knowledge about social role of Internet. Technological } \\
\text { limitations. Knowledge about role of Internet in } \\
\text { communications. Knowledge about transaction costs. } \\
\text { Knowledge about impact of Internet on business }\end{array}$ \\
\hline $\begin{array}{l}\text { O’Keefe et al., } \\
1998\end{array}$ & $\begin{array}{l}\text { E-commerce } \\
\text { adoption }\end{array}$ & $\begin{array}{l}173 \text { small firms that commercialize } \\
\text { retail products on Internet }\end{array}$ & International scope. Access to target public. Low cost \\
\hline $\begin{array}{l}\text { Tan \& Teo, } \\
1998\end{array}$ & Internet adoption & 188 firms with HQ in Singapore & Perceived advantages and disadvantages of using Internet \\
\hline $\begin{array}{l}\text { Doherty et al., } \\
1999\end{array}$ & $\begin{array}{l}\text { Website } \\
\text { development }\end{array}$ & 330 retailers with HQ in UK & $\begin{array}{l}\text { Strategic evaluation of impact of Internet. Resources } \\
\text { available. Competitive pressure. Perceived advantages of e- } \\
\text { commerce }\end{array}$ \\
\hline $\begin{array}{l}\text { Chan \& } \\
\text { Swatman, } 2000\end{array}$ & $\begin{array}{l}\text { E-commerce } \\
\text { adoption process }\end{array}$ & $\begin{array}{l}1 \text { steel manufacturer with HQ in } \\
\text { Australia (case study) }\end{array}$ & $\begin{array}{l}\text { Complexity of technology. Technological compatibility. } \\
\text { Commitment and support of management. Resistance to } \\
\text { change. Relationship with "trading partner" }\end{array}$ \\
\hline $\begin{array}{l}\text { Chappell \& } \\
\text { Feindt, 2000; }\end{array}$ & $\begin{array}{l}\text { Success in } \\
\text { implementing e- }\end{array}$ & $\begin{array}{l}27 \text { SMEs with HQ in Europe engaged } \\
\text { in e-commerce (qualitative) }\end{array}$ & $\begin{array}{l}\text { Presentation of supply. Usability of web site. Process control. } \\
\text { Relationship with customers. Relationship with other interest }\end{array}$ \\
\hline
\end{tabular}




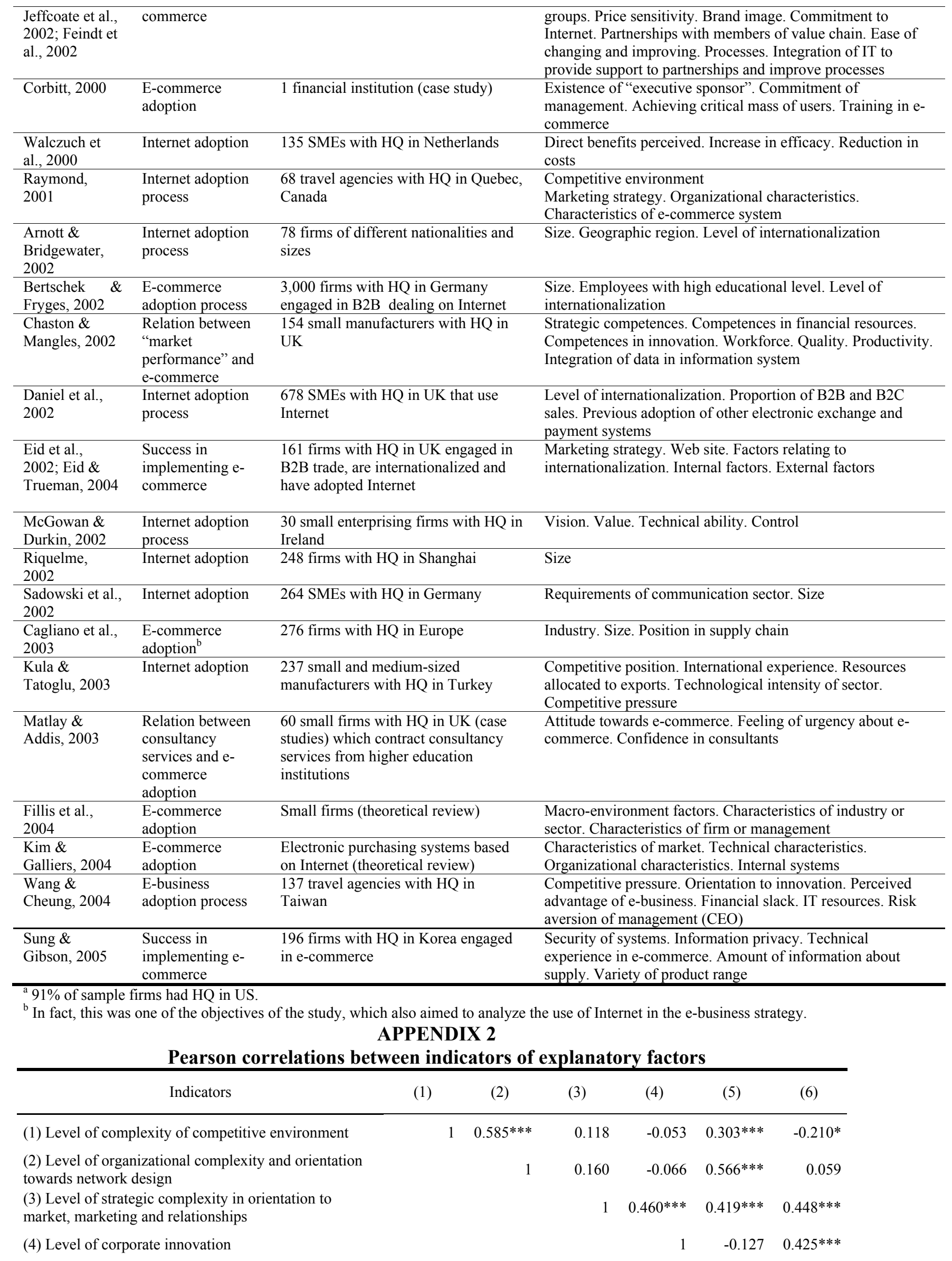


